\title{
Divergent effects of obesity on fragility fractures
}

This article was published in the following Dove Press journal:

Clinical Interventions in Aging

24 September 2014

Number of times this article has been viewed

\section{Carla Caffarelli \\ Chiara Alessi \\ Ranuccio Nuti \\ Stefano Gonnelli}

Department of Medicine, Surgery and Neuroscience, University of Siena, Siena, Italy
Correspondence: Stefano Gonnelli Department of Medicine, Surgery and Neuroscience, University of Siena, Policlinico Le Scotte, Viale Bracci 2, 53100 Siena, Italy Tel +390577585468

Fax +390577233446

Email gonnelli@unisi.it
Abstract: Obesity was commonly thought to be advantageous for maintaining healthy bones due to the higher bone mineral density observed in overweight individuals. However, several recent studies have challenged the widespread belief that obesity is protective against fracture and have suggested that obesity is a risk factor for certain fractures. The effect of obesity on fracture risk is site-dependent, the risk being increased for some fractures (humerus, ankle, upper arm) and decreased for others (hip, pelvis, wrist). Moreover, the relationship between obesity and fracture may also vary by sex, age, and ethnicity. Risk factors for fracture in obese individuals appear to be similar to those in nonobese populations, although patterns of falling are particularly important in the obese. Research is needed to determine if and how visceral fat and metabolic complications of obesity (type 2 diabetes mellitus, insulin resistance, chronic inflammation, etc) are causally associated with bone status and fragility fracture risk. Vitamin $\mathrm{D}$ deficiency and hypogonadism may also influence fracture risk in obese individuals. Fracture algorithms such as FRAX ${ }^{\circledR}$ might be expected to underestimate fracture probability. Studies specifically designed to evaluate the antifracture efficacy of different drugs in obese patients are not available; however, literature data may suggest that in obese patients higher doses of the bisphosphonates might be required in order to maintain efficacy against nonvertebral fractures. Therefore, the search for better methods for the identification of fragility fracture risk in the growing population of adult and elderly subjects with obesity might be considered a clinical priority which could improve the prevention of fracture in obese individuals.

Keywords: bone mineral density, BMI, prevention

\section{Introduction}

Obesity and osteoporosis are two public health problems with an increasing prevalence and high impact on morbidity and mortality which, during the last two decades, have become major health threats worldwide. ${ }^{1-3}$ Osteoporosis is a systemic skeletal disease characterized by low bone mineral density (BMD) and microarchitectural deterioration of bone tissue leading to an increased risk of developing spontaneous and traumatic bone fractures. ${ }^{3}$ The World Health Organization (WHO) defines obesity as abnormal or excessive fat accumulation that presents a risk for health. The body mass index (BMI) is a simple way of measuring the degree of obesity. ${ }^{4}$ WHO defines obesity as a BMI of $\geq 30 \mathrm{~kg} / \mathrm{m}^{2}$, overweight as BMI $25-29.9 \mathrm{~kg} / \mathrm{m}^{2}$, and underweight as $\mathrm{BMI}<18.5 \mathrm{~kg} / \mathrm{m}^{2}$.

Obesity, as defined according to WHO criteria, has more than doubled worldwide in the last 30 years. The prevalence of obesity in the US is estimated to be $34 \%$ and $37 \%$ of women and men, respectively; whereas in Europe it is estimated to be $23 \%$ of women and $20 \%$ of men. ${ }^{1,2}$ The prevalence of obesity is destined to grow worldwide and, for example, it is projected that by $2025,47 \%$ of men and $36 \%$ of women in the UK will be obese, carrying a highly elevated cost to the National Health Service. ${ }^{5,6}$ In addition, obese subjects present an increased risk of being affected by type 2 diabetes 
mellitus, hypertension, dyslipidemia, and cardiovascular diseases, and also have an increased risk of developing some types of cancer. However, for many years body weight has been considered one of the important determinants of BMD and positive relationships between body weight and BMD, or between BMI and BMD have been reported. ${ }^{7}$ An inverse relationship between body weight or BMI and the risk of any fractures has also been shown. ${ }^{8}$ In particular, obese women have always been considered protected against osteoporosis and osteoporotic fractures. However, in recent years the association between obesity and osteoporosis has been actively investigated from epidemiological, clinical, and basic research points-of-view, making it evident that osteoporosis and obesity can no longer be considered antithetic, instead they are closely connected and may present common pathophysiological mechanisms. Extensive epidemiological studies have reported that elevated body weight or BMI are positively correlated with increased BMD and with reduced risk of fragility fractures in both men and women. ${ }^{8}$ The generally accepted explanation of this relationship is that a larger body mass induces greater mechanical loading on bone, with a consequent increase in BMD to accommodate the greater load. ${ }^{8}$

Many studies have reported that in healthy premenopausal and postmenopausal women total body fat is positively related to $\mathrm{BMD}$, which is commonly considered the most important measurable determinant of fracture risk, and that decreased body weight leads to bone loss. ${ }^{9-11}$ On this basis low body weight has been incorporated into the FRAX $^{\circledR}$ and Garvan algorithms, calculations aimed to predict an individual's prospective fracture risk. In recent years there has been a growing interest in studying the influence of body composition on bone status and in particular the relationship between fat mass and BMD. The major mechanisms by which fat mass may influence bone tissue have recently been reviewed by several authors. ${ }^{9-11}$ Abundant fat mass might have several positive effects. Firstly, mechanical loading stimulates bone formation by decreasing apoptosis and increasing proliferation and differentiation of osteoblasts and osteocytes through the Wnt/ $\beta$-catenin signaling pathway. ${ }^{9,10}$ Therefore, mechanical loading is the basis of the assumption that has led to the belief that obesity may prevent bone loss and osteoporosis. ${ }^{12,13}$ Moreover, abundant adipose tissue is considered an important source of estrogen production, by an increased aromatization of androgens to estrogens, and may contribute to increased BMD. On the other hand, the association between fat mass and $\mathrm{BMD}$ has been reported to be stronger in women than in men. ${ }^{13,14}$ Also, many hormones may link fat mass to bone tissue. An excess of fat mass is associated with an increased secretion of insulin and amylin from pancreatic $\beta$-cells, decreased sex hormone binding globulin serum levels with increased levels of free sex steroids, and changes in the production of adipokines, among the more studied being leptin and adiponectin. ${ }^{9}$ Leptin, the most widely recognized adipocyte-derived hormone, is mainly known for its function of suppressing appetite and increasing energy expenditure, and is considered to play a crucial role in the protective effect of fat on bone. However, in vitro studies have recently confirmed that the effect of leptin on bone is complex and some cross-sectional studies assessing the role of leptin on BMD have reported both negative and positive effects. ${ }^{9}{ }^{15,16}$ Adiponectin, an adipocyte-produced hormone that correlates negatively with obesity in general, and central adiposity in particular, has been reported to stimulate both bone formation and bone resorption, but its effect on BMD remains controversial. ${ }^{9,15,16}$ Recently, some studies, mainly by Chinese authors, have contributed to the clarification of these points. ${ }^{17-18}$ In a large-scale sample of Chinese and Caucasian subjects, Zhao et $\mathrm{al}^{17}$ found that there is a positive correlation between fat mass and bone mass in both sexes, when results are not corrected for the mechanical loading effect of body weight. However, when the mechanical loading effect caused by total body weight is statistically removed, both fat mass and percentage fat are negatively correlated with bone mass. ${ }^{17}$ Consistent with this finding two more recent studies, carried out on large cohorts of Chinese and Korean subjects, found that subjects with a higher percentage of body fat presented lower BMD and a higher prevalence of osteoporosis. ${ }^{18,19}$ In the same period Premaor et $\mathrm{al}^{20}$ reported that, of postmenopausal women with low trauma fracture attending a Fracture Liaison Service in the UK over a 2-year period, $28 \%$ were obese, and that in the majority of these obese women BMD was in the normal range. More recently the Global Longitudinal study of Osteoporosis in Women (GLOW), a large multinational study of women aged $>55$ years, has reported similar rates of clinical fractures in obese and nonobese women, with $23 \%$ and $22 \%$ of all previous and incident fractures, respectively, occurring in obese women. ${ }^{21}$

\section{Pathophysiology of bone fragility in obesity}

In recent years there has been a growing interest in studying the relationships between fat mass, BMD, and bone fragility. The possible mechanisms by which obesity may influence bone fragility and, consequently, fragility fracture risk are listed in Table 1. One possible mechanism may 
Table I Potential pathogenetic mechanisms for fragility fractures in obese individuals

- Increased production of proinflammatory cytokines

- Insulin resistance

- Vitamin D deficiency

- Secondary hyperparathyroidism

- Hypogonadism

- Muscular impairment

- Calcium malabsorption

- Comorbidities and comedications

be represented by the fact that obesity is now known as a systemic inflammatory condition and that adipose tissue secretes various inflammatory cytokines, mainly interleukin 6 (IL-6) and tumor necrosis factor- $\alpha$ (TNF- $\alpha$ ) which may upregulate the receptor activator of nuclear factor $\mathrm{k}$ ligands (RANKL), stimulating osteoclastogenesis and leading to bone resorption. ${ }^{10,22}$ Moreover, it has been reported that the production of proinflammatory cytokines is higher in abdominal fat than in subcutaneous fat, whereas aromatase activity and adiponectin secretion are lower in visceral than in subcutaneous fat. ${ }^{23,24}$ The proinflammatory cytokines are involved in the regulation of other adipokines, in particular, increased IL- 6 and TNF- $\alpha$ production by adipose tissue was associated with a reduced production of adiponectin, an adipokine which seems to have a protective effect on bone. ${ }^{16}$ Moreover, increased IL- 6 and TNF- $\alpha$ production by adipose tissue is associated with insulin resistance, type 2 diabetes mellitus, and atherosclerosis, pathological conditions that, in turn, could impair bone strength. ${ }^{24,25}$ Also, Amati et al reported that both lower thigh subcutaneous and higher visceral abdominal adipose tissue contribute to insulin resistance. ${ }^{26}$ At present, the association between insulin resistance and bone mass still remains unclear. Recent literature data have reported that although insulin is a potent regulator of bone growth and directly stimulates osteoblasts in vitro, the insulin resistance negatively influences bone status. ${ }^{9,11}$ In fact, in a nationally representative sample of Korean men, both insulin resistance status and fasting serum insulin levels were inversely associated with bone mass. ${ }^{27}$ However, a study carried out by Choi et $\mathrm{al}^{28}$ on a large cohort of Korean and US subjects, has suggested that the adverse influence of insulin on bone mass likely reflects the effects of other factors associated with insulin resistance than being a direct action of insulin itself. ${ }^{28}$ Moreover, high insulin levels might reduce the carboxylation of osteocalcin and increase RANKL production, so resulting in increased bone resorption. ${ }^{29}$ Recent evidence has also reported that obesity, and particularly abdominal obesity, is characterized by increased serum levels of C-reactive protein, an inflammatory marker which has been associated with lower BMD, higher levels of bone turnover markers and, more recently, greater risk of fracture, further suggesting an important role of inflammation in bone impairment in obese subjects. ${ }^{10}$ In fact, high fat-induced obese animals exhibited increased bone marrow adiposity accompanied by upregulation of peroxisome proliferator-activated receptor gamma, IL-6, and TNF- $\alpha$, and reduced BMD. ${ }^{30}$

It is well known that obesity is associated with reduced levels of 25-hydroxyvitamin D, and that fat mass and 25-hydroxyvitamin D are inversely related. This has been attributed to sequestration of this fat-soluble vitamin in adipose tissue, though there is also evidence that vitamin $\mathrm{D}$ inhibits development of adipocytes. ${ }^{9,31}$ Moreover, it has been reported that parathyroid hormone $(\mathrm{PTH})$ concentrations are directly correlated with fat mass and inversely associated with 25-hdroxyvitamin D levels, whereas other studies did not find any relationship between PTH and 25-hydroxyvitamin D. ${ }^{31,32}$ The increased levels of PTH may determine a greater impairment of cortical bone and offer an explanation for the major prevalence of fractures in skeletal sites where cortical bone prevails such as the humerus, ankle, and upper arm. ${ }^{33}$

In males, obesity is considered an important risk factor for hypogonadism. ${ }^{34}$ Hypogonadism, obesity, erectile dysfunction, insulin resistance, and metabolic syndrome often coexist in the same subjects who are considered to be at increased risk of falls and fractures. ${ }^{34}$ Moreover, in some individuals there is an inverse association between accumulation of body fat and the decrease in muscle mass and/or function. This condition, termed "sarcopenic obesity", probably due to proinflammatory factors produced by adipose tissue, represents a further risk for falls and fractures. ${ }^{35}$ In fact, although greater soft tissue padding may reduce skeletal trauma following a fall, poorer protective responses to falling due to muscle weakness and the higher impact of the fall owing to high body weight may offset this potential benefit. Finally, a high-fat diet, often a cause of obesity, has been reported to interfere with intestinal calcium absorption. Free fatty acids can form unabsorbable, insoluble calcium soaps and therefore contribute to low calcium absorption. ${ }^{10}$ Furthermore, as the association between obesity and fractures is markedly influenced by sex, the studies reporting data on this point should be considered separately according to sex.

\section{Obesity and fractures in postmenopausal women and in men}

Many epidemiological studies have reported that low body weight and low BMI are risk factors for fragility fracture. 
In particular, the results of a meta-analysis of 60,000 men and women from 12 prospective, population-based cohorts showed that total fractures, osteoporotic fractures, and hip fractures were all inversely correlated to BMI in both men and women, but these associations were lost after adjustment for BMD, with the exception of hip fracture. ${ }^{8}$ Moreover, in the study by Schott et al carried out on a large population of almost 8,000 French women $>75$ years old, there was a $40 \%$ increase in hip fracture risk for each standard deviation decrease in fat mass, whereas the fracture risk was not influenced by lean mass. ${ }^{36}$ The study by Premaor et al evaluated 1,005 postmenopausal women $<75$ years of age presenting to a Fracture Liaison Service in Cambridge (UK) with a low trauma fracture, and reported that fractures of the wrist were significantly less common and hip fractures significantly more common in obese compared to nonobese women. ${ }^{20}$ The GLOW study, a prospective cohort study involving 723 physician practices in ten countries, has reported that the risk of incident ankle and upper leg fractures was significantly higher in obese than nonobese women, while the risk of wrist fracture was significantly lower. ${ }^{21}$ A previous Italian study, carried out on 2,235 Italian postmenopausal women with fracture, reported that increased BMI was associated with a significantly higher risk of humerus fracture and a lower risk of hip fracture, whereas no relationship was seen between BMI and either wrist or ankle fractures. ${ }^{37}$ Using data from the Womens' Health Initiative (WHI) study in postmenopausal women, Beck et al reported that overweight and obese women presented a higher incidence of lower-extremity and a lower incidence of hip fractures with respect to normal weight women. ${ }^{38}$ A recent prospective study by Prieto-Alhambra et al carried out on 832,775 Spanish women aged $>50$ years visiting general practitioners has confirmed that obesity is protective against hip and pelvis fractures, but is associated with an almost $20 \%$ increase in risk for proximal humerus fracture. ${ }^{39}$ Data on vertebral fractures in obese subjects are scarce, although in an Italian study carried out on a small cohort of postmenopausal women higher BMI appeared to be associated with a higher likelihood of having vertebral fractures, irrespective of the positive association between weight and BMD. ${ }^{40}$

Some recent studies carried out on Korean, Australian, and Japanese postmenopausal women reported that obesity was associated with an increased risk of vertebral fractures, whereas another Australian study found a protective effect of abdominal fat on vertebral fractures in women, but not in men. ${ }^{19,41-43}$ A recent analysis using data from the Nottingham Fracture Liaison Service reported that obese subjects were more likely to fracture their ankle and upper arm, but were less likely to fracture their wrist. ${ }^{44}$ Also, two studies carried out in adult men and women reported that ankle fracture was significantly related to obesity. ${ }^{45,46}$ A prospective study by the Osteoporotic Fractures in Man Research Group reported that obesity was associated with an increased risk of nonvertebral fractures in men aged $>65$ years after adjustment for BMD, whilst in a large population-based study of Spanish men, an increase in multiple rib fractures was reported in overweight and obese men aged $\geq 65$ years. ${ }^{47,48}$ Conversely, this latter study reported a protective effect of obesity for hip, wrist, and clinical spine fractures in elderly males. ${ }^{48}$ Tables 2 and 3 summarize the results of the studies published in the last 5 years.

At present, literature data suggest that in postmenopausal women obesity is associated with an increased risk in ankle, other lower limb, and humerus fractures, and a reduced risk

Table 2 Obesity and fracture in men (2009-2014)

\begin{tabular}{|c|c|c|c|c|c|c|}
\hline Reference & Country & Population & $\begin{array}{l}\text { Assessment } \\
\text { of obesity }\end{array}$ & $\begin{array}{l}\text { Increased } \\
\text { fractures } \\
\text { (skeletal sites) }\end{array}$ & $\begin{array}{l}\text { Reduced } \\
\text { fractures } \\
\text { (skeletal sites) }\end{array}$ & $\begin{array}{l}\text { Study } \\
\text { characteristics }\end{array}$ \\
\hline Nielson et $\mathrm{al}^{47}$ & USA & $\begin{array}{l}5,995 \text { men } \\
\geq 65 \text { years }\end{array}$ & BMI & Hip, non-spine & - & Longitudinal \\
\hline Laslett et $\mathrm{al}^{41}$ & Australia & $\begin{array}{l}489 \text { men aged } \\
50-80 \text { years }\end{array}$ & $\begin{array}{l}\text { BMI, total fat, waist } \\
\text { circumference }\end{array}$ & - & Vertebrae & Cross-sectional \\
\hline Premaor et $\mathrm{al}^{48}$ & Spain & $\begin{array}{l}139,419 \text { men } \\
\geq 65 \text { years }\end{array}$ & $\mathrm{BMI}$ & Rib & $\begin{array}{l}\text { Hip, spine, wrist/ } \\
\text { forearm, pelvis }\end{array}$ & Cohort \\
\hline Jordan et $\mathrm{al}^{46}$ & Thailand & $\begin{array}{l}25,865 \text { men aged } \\
19-49 \text { years }\end{array}$ & BMI & - & - & Cohort \\
\hline Ong et $\mathrm{al}^{44}$ & UK & $\begin{array}{l}722 \text { men aged } \\
50-70 \text { years }\end{array}$ & BMI & $\begin{array}{l}\text { Upper forearm, } \\
\text { ankle }\end{array}$ & Wrist & Cross-sectional \\
\hline Yang et $\mathrm{al}^{43}$ & Australia & $\begin{array}{l}360 \text { men } \\
\geq 50 \text { years }\end{array}$ & $\begin{array}{l}\text { Total and } \\
\text { abdominal fat mass }\end{array}$ & - & - & Prospective \\
\hline
\end{tabular}

Abbreviation: BMI, body mass index. 
Table 3 Obesity and fracture in women (2009-2014)

\begin{tabular}{|c|c|c|c|c|c|c|}
\hline Reference & Country & Population & $\begin{array}{l}\text { Assessment } \\
\text { of obesity }\end{array}$ & $\begin{array}{l}\text { Increased } \\
\text { fractures } \\
\text { (skeletal sites) }\end{array}$ & $\begin{array}{l}\text { Reduced } \\
\text { fractures } \\
\text { (skeletal sites) }\end{array}$ & $\begin{array}{l}\text { Study } \\
\text { characteristics }\end{array}$ \\
\hline Compston et $\mathrm{al}^{21}$ & UK & $\begin{array}{l}60,393 \text { women } \\
\geq 55 \text { years }\end{array}$ & BMI & Upper leg, ankle & Wrist & Longitudinal \\
\hline Premaor et $\mathrm{al}^{20}$ & UK & $\begin{array}{l}\mathrm{I}, 005 \text { women } \\
\geq 75 \text { years }\end{array}$ & $\mathrm{BMI}$ & Hip & Wrist & Cross-sectional \\
\hline Gnudi et $\mathrm{al}^{37}$ & Italy & 2,235 PM women & $\mathrm{BMI}$ & Humerus & Hip & Cross-sectional \\
\hline Beck et $\mathrm{al}^{38}$ & USA & $\begin{array}{l}78,013 \text { women } \\
\text { aged } 50-79 \text { years }\end{array}$ & $\mathrm{BMI}$ & Lower extremity & Hip, vertebrae & Longitudinal \\
\hline Prieto-Alhambra et al ${ }^{39}$ & Spain & $\begin{array}{l}832,775 \text { women } \\
\geq 50 \text { years }\end{array}$ & $\mathrm{BMI}$ & Humerus & Hip, pelvis & Cross-sectional \\
\hline Pirro et $\mathrm{al}^{40}$ & Italy & 362 PM women & BMI & Vertebrae & - & Cross-sectional \\
\hline Kim et al ${ }^{19}$ & Korea & $\begin{array}{l}907 \text { women aged } \\
50-80 \text { years }\end{array}$ & $\begin{array}{l}\text { BMI, waist } \\
\text { circumference }\end{array}$ & Vertebrae & - & Cross-sectional \\
\hline Laslett et $\mathrm{al}^{4 \mathrm{I}}$ & Australia & $\begin{array}{l}522 \text { women aged } \\
50-80 \text { years }\end{array}$ & $\begin{array}{l}\text { BMI, total fat, waist } \\
\text { circumference }\end{array}$ & Vertebrae & - & Cross-sectional \\
\hline Tanaka et $\mathrm{al}^{42}$ & Japan & $\begin{array}{l}\mathrm{I}, 6 \mathrm{I} 4 \text { postmenopausal } \\
\text { women } \geq 50 \text { years }\end{array}$ & $\mathrm{BMI}$ & Vertebrae & Hip & Longitudinal \\
\hline Ong et $\mathrm{al}^{44}$ & UK & $\begin{array}{l}3,566 \text { women aged } \\
50-70 \text { years }\end{array}$ & $\mathrm{BMI}$ & $\begin{array}{l}\text { Ankle, upper } \\
\text { arm }\end{array}$ & Wrist & Cross-sectional \\
\hline Jordan et $\mathrm{al}^{46}$ & Thailand & $\begin{array}{l}32,339 \text { women aged } \\
19-40 \text { years }\end{array}$ & $\mathrm{BMI}$ & Ankle, leg & - & Cohort \\
\hline Yang et $\mathrm{al}^{43}$ & Australia & $\begin{array}{l}766 \text { women } \\
\geq 50 \text { years }\end{array}$ & $\begin{array}{l}\text { Total and } \\
\text { abdominal fat mass }\end{array}$ & - & Vertebrae & Prospective \\
\hline
\end{tabular}

Abbreviations: BMI, body mass index; PM, postmenopausal.

in hip, pelvis, and wrist fractures. In males, data are less available, however, it is possible to demonstrate a similar pattern. Indeed, the reasons for site-specific differences in fracture risk in obese compared with nonobese individuals have not yet been established. A number of factors could explain the site distribution of fractures. In fact, soft tissue padding may protect against pelvis and hip fractures in obese subjects. Obese subjects tend to fall backward or sideways rather than forward, and this, together with impaired protective reactions to falling, may protect the wrist from the impact. On the other hand, the additional body weight in obesity may increase the force of a fall beyond that which can be accommodated by the arm. To date, the reasons for increased fracture risk at ankle and leg in obese individuals still remain unclear, but it is possible that excessive stresses (introversion/extroversion and bending/torsion) are involved. ${ }^{11,49}$ In addition, reduced levels of 25-hydroxyvitamin D and the consequent higher serum PTH levels reported in obese individuals could have an adverse effect on cortical bone. ${ }^{31,33}$

Although some previous studies, generally carried out in Asian populations, have suggested an inverse association between visceral adipose tissue and BMD, the impact of regional fat distribution on BMD still remains controversial. The uncertainty in the literature may be due to the fact that the majority of studies were carried out using dual-energy $\mathrm{X}$-ray absorptiometry technique which is not able to precisely distinguish between subcutaneous and visceral fat. The fact that most of the previously mentioned studies have been conducted on women of Asian origin may contribute to the uncertainty of literature data. In particular, it has been reported that for the same BMI, Asians had higher percentage body fat and abdominal obesity components, compared with those of Caucasian subjects, which may be deleterious for bone. ${ }^{50}$

\section{Evaluation of fracture risk in obese subjects}

The identification of patients with high fragility fracture risk before they have fractures might be considered a clinical priority which could improve the prevention of fractures. However, there is growing awareness of the inadequacy of current methods to predict fracture risk in obese patients, who constitute a substantial portion of the older population. In obese patients, laboratory assessment does not offer any extra information but is essential for a comprehensive evaluation of the fracture risk. In addition to standard laboratory tests, it is important to assess the level of glycemic control by blood glucose profiles and, $\mathrm{HbA}_{1 \mathrm{c}}$, the serum levels of 25-hydroxyvitamin $\mathrm{D}$ and to calculate the glomerular filtration rate. The measurement of 
bone turnover markers, namely bone-specific alkaline phosphatase and Serum CrossLaps ${ }^{\circledR}$, could be useful in differential diagnosis and for the monitoring of treatment response.

Although BMD is significantly higher in obese women with fractures than in their nonobese counterparts, obese women with fracture have a significantly lower BMD at both the lumbar spine and femoral neck when compared with women of similar age and weight without fractures. ${ }^{48}$ These findings suggest that BMD may be inappropriately low in those obese subjects who fracture and also confirms the importance of BMD evaluation in obese individuals. However, since obese individuals generally have higher BMI and BMD, fracture algorithms such as FRAX might be expected to underestimate fracture probability. The predictive value of FRAX in obese older women who were participating in the Study of Osteoporotic Fractures study have been recently assessed by Premaor et al. ${ }^{51}$ In this latter study the 10-year probability of hip fracture was $10.9 \%$ and $7.1 \%$ in nonobese and obese postmenopausal women, respectively; whereas, the 10 -year probability of major osteoporotic fracture in nonobese and obese postmenopausal women was $23.3 \%$ and $18.2 \%$, respectively. ${ }^{51}$ However, the area under the curve determined by receiver operating curve analysis was similar in nonobese and obese women. ${ }^{51}$ Therefore, the FRAX-based intervention thresholds (eg, $>20 \%$ probability of a major osteoporotic fracture or $>3 \%$ probability of hip fracture in the following 10 years) are probably too high for obese patients and should be reduced. Unfortunately, at present no data are available to supply any information regarding the real necessity and the significance of such a reduction. ${ }^{11,49}$ Literature data suggest that poor metabolic health associated with obesity may impair bone strength and/or density; therefore, obese subjects with a waist circumference exceeding published cut-points, type 2 diabetes, or insulin resistance may be at higher risk for fragility fractures. ${ }^{49}$ However, at present, it is not known whether the incorporation of such parameters into the FRAX algorithm may ameliorate fracture prediction. Finally, X-ray evaluation of the thoracolumbar spine should be considered in case of progressive back pain, kyphosis, or substantial height loss to check for possible vertebral fractures. In fact, the presence of vertebral fractures may be expected to increase the risk of further vertebral, nonvertebral, and hip fractures.

\section{Prevention of fragility fractures in obese subjects \\ Calcium and vitamin D supplementation}

In obese patients, any deficiencies in calcium and vitamin $\mathrm{D}$ should be prevented and treated before specific osteoporosis drugs are started; however, at present there are no specific guidelines for calcium/vitamin D supplementation in obese patients. The National Institute of Health in the USA proposes a recommended dietary allowance for calcium of 1,000 $\mathrm{mg}$ in men aged 50-70 years, and 1,200 $\mathrm{mg}$ in men $>70$ years and women $>50$ years. The recommended daily calcium intake should ideally be reached through the diet, and calcium supplementation should be restricted to whenever the dietary intake is inadequate or, for whatever reason, cannot be optimized with diet. In fact, recent studies have reported that high doses of calcium supplementation may increase the deposit of calcium at the level of atherosclerotic plaques and may represent a risk factor for myocardial infarction and other cardiovascular diseases. ${ }^{52}$ Vitamin D deficiency is common among elderly subjects and it is thought to contribute to bone loss by stimulating PTH secretion, with consequent increased bone resorption. Vitamin D supplementation should ensure serum 25-hydroxyvitamin D levels of $75 \mathrm{nmol} / \mathrm{L}(=30 \mathrm{ng} / \mathrm{mL})$, since previous studies have reported that bone mineralization defects were not seen if serum 25-hydroxyvitamin D levels were $>75 \mathrm{nmol} / \mathrm{L} .{ }^{53}$ As the majority of subjects cannot reach the threshold of $30 \mathrm{ng} / \mathrm{mL}$ by consuming foods rich in vitamin $\mathrm{D}$ or sun exposure, a supplementation of 800-2,000 IU of vitamin D per day is recommended. Obese patients require higher doses of vitamin $\mathrm{D}(>3,000$ IU daily) because of a larger volume of distribution and the accumulation of vitamin $D$ in the adipose tissue. Since the adherence to daily regimens of vitamin D supplementation may be low, higher intermittent doses (25,000 IU monthly or 100,000 every 4 months) have been proposed, which should improve treatment adherence. ${ }^{54}$ However, recent studies reported that the use of vitamin D boluses exceeding 100,000-300,000 IU may be associated with an unexpected increase in bone resorption and in fracture rate. ${ }^{55}$ The ability of vitamin $\mathrm{D}$ in reducing falls in the elderly has been observed in several studies and in a double-blind, randomized controlled trial by Bischoff et $\mathrm{al}^{56}$ carried out in a cohort of 122 elderly women without type 2 diabetes mellitus (mean age 85.3 years). In this study the participants were randomized to receive $1,200 \mathrm{mg}$ calcium plus $800 \mathrm{IU}$ cholecalciferol or 1,200 mg calcium per day over a 12-week treatment period. The results showed that the vitamin D plus calcium supplementation reduced the number of falls per person by $49 \%$, improved musculoskeletal function, and decreased PTH levels and bone resorption markers. These findings support the necessity for all obese patients to have adequate serum levels of vitamin D assured. 


\section{Pharmacological therapy}

In recent years the therapeutic alternatives for the prevention and treatment of osteoporotic fractures have notably increased in number, and today comprise numerous drugs with different mechanisms of action. However, studies specifically designed to evaluate the antifracture efficacy of different drugs in obese patients are not available and pivotal trials ${ }^{58-60}$ included relatively few obese individuals. In addition, a recent study carried out in the GLOW population reported that obese women with fracture are more frequently undertreated than those nonobese (27\% versus $41 \%) .{ }^{57}$ At present, the only available data are those regarding anticatabolic drugs. In a study of the effects of clodronate in postmenopausal women, the reduction in nonvertebral fractures in obese women was not significant, whereas a significant reduction was observed in nonobese women. ${ }^{58}$ Moreover, the subgroup analyses of the HORIZON study and of the FREEDOM study reported that the reduction in vertebral fractures were similar in obese and nonobese osteoporotic women, whereas the reduction in nonvertebral fractures was significant only in those women with a BMI $<25 \mathrm{~kg} / \mathrm{m}^{2}{ }^{58,60}$ These data, probably due to the small numbers of obese women enrolled in the studies, may suggest that higher doses of bisphosphonates in obese patients might be required in order to maintain the efficacy against nonvertebral fractures..$^{59,60}$ At present no data exist in the literature regarding the efficacy of strontium ranelate and teriparatide in obese patients.

\section{Conclusion}

Even though the incidence and the pathogenesis of fracture in obese individuals have not yet been clearly defined, the growing evidence that obesity may be related to an increased risk of fracture has important public health implications. Therefore, the search for better methods for the identification of fragility fracture risk in the growing population of adult and elderly subjects with obesity might be considered a clinical priority which could improve the prevention of fracture in these patients.

\section{Disclosure}

The authors report no conflicts of interest in this work.

\section{References}

1. World Health Organization health topics: Obesity [webpage on the Internet]. Geneva: Switzerland; 2014. Available from: http://www.who. int/topics/obesity/en/. Accessed 28 Apr 2014.

2. World Health Organization [webpage on the Internet]. Available from: http:/www.euro.who.int/en/health-topics/noncommunicable-diseases/ obesity/data-and-statistics. Accessed 28 Apr 2014.
3. NIH Consensus Development Panel on Osteoporosis Prevention, Diagnosis and Therapy. Osteoporosis prevention, diagnosis, and therapy. JAMA. 2001;285(6):785-795.

4. World Health Organization. Obesity: preventing and managing the global endemic, WHO Technical Report Series No 894. Geneva, Switzerland: World Health Organization; 2000.

5. Flegal KM, Carrol MD, Ogden CL, Curtin LR. Prevalence and trends in obesity among US adults, 1999-2008. JAMA. 2010;303(3):235-241.

6. Finucane MM, Stevens GA, Cowan MJ, et al; Global Burden of Metabolic Risk Factors of Chronic Diseases Collaborating Group (Body Mass Index). National, regional, and global trends in body-mass index since 1980: systematic analysis of health examination surveys and epidemiological studies with 960 country-years and 9.1 million participants. Lancet. 2011;377(9765):557-567.

7. Khosla S, Atkinson EJ, Riggs BL, Melton LJ 3rd. Relationship between body composition and bone mass in women. J Bone Miner Res. 1996; 11(6):857-863.

8. De Laet C, Kanis JA, Odén A, et al. Body mass index as a predictor of fracture risk: a meta-analysis. Osteoporos Int. 2005;16(11) 1330-1338.

9. Reid IR. Fat and bone. Arch Biochem Biophys. 2010;503(1):20-27.

10. Cao JJ. Effects of obesity on bone metabolism. J Orthop Surg Res. 2011; 6:30.

11. Compston J. Obesity and Bone. Curr Osteoporos Rep. 2013;11(1): 30-35.

12. Felson DT, Zhang Y, Hannan MT, Anderson JJ. Effects of weight and body mass index on bone mineral density in men and women: the Framingham study. J Bone Miner Res. 1993;8(5):567-573.

13. Reid IR. Relationships among body mass, its components, and bone. Bone. 2002;31(5):547-555.

14. Gonnelli S, Caffarelli C, Tanzilli L, et al. The associations of body composition and fat distribution with bone mineral density in elderly Italian men and women. J Clin Densitom. 2013;16(2):168-177.

15. Kontogianni MD, Dafni UG, Routsias JG, Skopouli FN. Blood leptin and adiponectin as possible mediators of the relation between fat mass and BMD in perimenopausal women. J Bone Miner Res. 2004;19(4): $546-551$.

16. Gonnelli S, Caffarelli C, Del Santo K, et al. The relationship of ghrelin and adiponectin with bone mineral density and bone turnover markers in elderly men. Calcif Tissue Int. 2008;83(1):55-60.

17. Zhao LJ, Jiang H, Papasian CJ, et al. Correlation of obesity and osteoporosis: effect of fat mass on the determination of osteoporosis. J Bone Miner Res. 2008;23(1):17-29.

18. Hsu YH, Venners SA, Terwedow HA, et al. Relation of body composition, fat mass, and serum lipids to osteoporotic fractures and bone mineral density in Chinese men and women. Am J Clin Nutr. 2006;83(1): $146-154$.

19. Kim CJ, Oh KW, Rhee EJ, et al. Relationship between body composition and bone mineral density (BMD) in perimenopausal Korean women. Clin Endocrinol (Oxf). 2009;71(1):18-26.

20. Premaor MO, Pilbrow L, Tonkin C, Parker RA, Compston J. Obesity and fractures in postmenopausal women. J Bone Miner Res. 2010;25(2): 292-297.

21. Compston JE, Watts NB, Chapurlat R, et al; Glow Investigators. Obesity is not protective against fracture in postmenopausal women: GLOW. Am J Med. 2011;124(11):1043-1050.

22. Barbour KE, Zmuda JM, Boudreau R, et al. The effects of adiponectin and leptin on changes in bone mineral density. Osteoporos Int. 2012; 23(6):1699-1710.

23. Blüher M. Adipose tissue dysfunction in obesity. Exp Clin Endocrinol Diabetes. 2009;117(6):241-250.

24. Xu H, Barnes GT, Yang Q, et al. Chronic inflammation in fat plays a crucial role in the development of obesity-related insulin resistance. J Clin Invest. 2003;112(12):1821-1830.

25. Bruun LM, Lihn AS, Verdich C, et al. Regulation of adiponectin by adipose tissue-derived cytokines: in vivo and in vitro investigations in humans. Am J Physiol Endocrinol Metab. 2003;285(3):E527-E533. 
26. Amati F, Pennant M, Azuma K, et al. Lower thigh subcutaneous and higher visceral abdominal adipose tissue content both contribute to insulin resistance. Obesity (Silver Spring). 2012;20(5):1115-1117.

27. Shin D, Kim S, Kim KH, Lee K, Park SM. Association between insulin resistance and bone mass in men. J Clin Endocrinol Metab. 2014;99(3): 998-995.

28. Choi YJ, Kim DJ, Lee Y, Chung YS. Insulin is inversely associated with bone mass, especially in the insulin-resistant population: the Korea and U.S. National Health and Nutrition Examination Surveys. J Clin Endocrinol Metab. 2014;99(4):1433-1441.

29. Clemens TL, Karsenty G. The osteoblast: an insulin target cell controlling glucose homeostasis. J Bone Miner Res. 2011;26(4):677-680.

30. Halade GV, Rahman MM, Williams PJ, Fernandes G. High fat dietinduced animal model of age-associated obesity and osteoporosis. J Nutr Biochem. 2010;21(12):1162-1169.

31. Bolland MJ, Grey AB, Ames RW, Horne AM, Gamble GD, Reid IR. Fat mass is an important predictor of parathyroid hormone levels in postmenopausal women. Bone. 2006;38(3):317-321.

32. Grethen E, McClintock R, Gupta CE, et al. Vitamin D and hyperparathyroidism in obesity. J Clin Endocrinol Metab. 2011;96(5):1320-1326.

33. Sukumar D, Schlussel Y, Riedt CS, Gordon C, Stahl T, Shapses SA. Obesity alters cortical and trabecular bone density and geometry in women. Osteoporos Int. 2011;22(2):635-645.

34. Orwoll E, Lambert LC, Marshall LM, et al; Osteoporotic Fractures in Men Study Group. Endogenous testosterone levels, physical performance, and fall risk in older men. Arch Intern Med. 2006;166(19):2124-2131.

35. Stenholm S, Harris TB, Rantanen T, et al. Sarcopenic obesity: definition, cause and consequences. Curr Opin Clin Nutr Metab Care. 2008; 11(6):693-700.

36. Schott AM, Cormier C, Hans D, et al. How hip and whole-body bone mineral density predict hip fracture in elderly women: the EPIDOS Prospective Study. Osteoporos Int. 1998;8(3):247-254.

37. Gnudi S, Sitta E, Lisi L. Relationship of bod mass index with main limb fragility fractures in postmenopausal women. J Bone Miner Metab. 2009;27(4):479-484.

38. Beck TJ, Petit MA, Wu G, LeBoff MS, Cauley JA, Chen Z. Does obesity really make the femur stronger? BMD, geometry, and fracture incidence in the women's health initiative-observational study. J Bone Miner Res. 2009;24(8):1369-1379.

39. Prieto-Alhambra D, Premaor MO, Fina Avilés F, et al. The association between fracture and obesity is site-dependent: a population-based study in postmenopausal women. J Bone Miner Res. 2012;27(2):294-300.

40. Pirro M, Fabbriciani G, Leli C, et al. High weight or body mass index increase the risk of vertebral fractures in postmenopausal osteoporotic women. J Bone Miner Metab. 2010;28(1):88-93.

41. Laslett LL, Just Nee Foley SJ, Quinn SJ, Winzenberg TM, Jones G. Excess body fat is associated with higher risk of vertebral deformities in older women but not in men: a cross-sectional study. Osteoporos Int. 2012;23(1):67-74.

42. Tanaka S, Kuroda T, Saito M, Shiraki M. Overweight/obesity and underweight are both risk factors for osteoporotic fractures at different sites in Japanese postmenopausal women. Osteoporos Int. 2013;24(1):69-76.

43. Yang S, Nguyen D, Center JR, Eisman JA, Nguyen TV. Association between abdominal obesity and fracture risk: a prospective study. J Clin Endocrinol Metab. 2013;98(6):2478-2483.
44. Ong T, Sahota O, Tan W, Marshall L. A United Kingdom perspective on the relationship between body mass index (BMI) and bone health: a cross sectional analysis of data from the Nottingham Fracture Liaison Service. Bone. 2014;59:207-210.

45. Bergkvist D, Hekmat K, Svensson T, Dahlberg L. Obesity in orthopedic patients. Surg Obes Relat Dis. 2009;5(6):670-672.

46. Jordan S, Lim L, Berecki-Gisolf J, et al; Thai Cohort Team. Body mass index, physical activity, and fracture among young adults: longitudinal results from the Thai Cohort Study. J Epidemiol. 2013;23(6): 435-442.

47. Nielson CM, Marshall LM, Adams AL, et al; Osteoporotic Fractures in Men Study Research Group. BMI and fracture risk in older men: the osteoporotic fractures in men study (MrOS). J Bone Miner Res. 2011; 26(3):496-502.

48. Premaor MO, Compston JE, Fina Avilés F, et al. The association between fracture site and obesity in men: a population-based cohort study. J Bone Miner Res. 2013;28(8):1771-1777.

49. Gower BA, Casazza K. Divergent effects of obesity on bone health. $J$ Clin Densitom. 2013;16(4):450-454.

50. Chung S, Song MY, Shin HD, et al. Korean and Caucasian overweight premenopausal women have different relationship of body mass index to percent body fat with age. J Appl Physiol (1985). 2005;99(1): 103-107.

51. Premaor MO, Parker RA, Cummings SR, et al; Study of Osteoporotic Fractures (SOF) Research Group. Predictive value of FRAX for fracture in obese older women. J Bone Miner Res. 2013;28(1):188-195.

52. Bolland MJ, Avenell A, Baron JA, et al. Effect of calcium supplements on risk of myocardial infarction and cardiovascular events: metaanalysis. BMJ. 2010;341:c3691

53. Holick MF. Vitamin D deficiency. N Eng J Med. 2007;357(3):266-281.

54. Bacon CJ, Gamble GD, Horne AM, Scott MA, Reid IR. High-dose oral vitamin D3 supplementation in the elderly. Osteoporos Int. 2009; 20(8):1407-1415.

55. Sanders KM, Stuart AL, Williamson EJ, et al. Annual high-dose oral vitamin D and falls and fractures in older women: a randomized controlled trial. JAMA. 2010;303(18):1815-1822.

56. Bischoff HA, St ähelin HB, Dick W, et al. Effects of vitamin D and calcium supplementation on falls: a randomized controlled trial. J Bone Miner Res. 2003;18(2):343-351.

57. Compston JE, Flahive J, Hooven FH, et al; GLOW Investigators. Obesity, health-care utilization, and health-related quality of life after fracture in postmenopausal women: Global Longitudinal Study of Osteoporosis in Women (GLOW). Calcif Tissue Int. 2014;94(2):223-231.

58. McClung M, Boonen S, T örring O, et al. Effect of denosumab treatment on the risk of fractures in subgroups of women with postmenopausal osteoporosis. J Bone Miner Res. 2012;27(1):211-218.

59. McCloskey EV, Johansson H, Oden A, et al. Ten-year fracture probability identifies women who will benefit from clodronate therapyadditional results from a double-blind, placebo-controlled randomised study. Osteoporos Int. 2009;20(5):811-817.

60. Eastell R, Black DM, Boonen S, et al; HORIZON Pivotal Fracture Trial. Effect of once-yearly zoledronic acid five milligrams on fracture risk and change in femoral neck bone mineral density. J Clin Endocrinol Metab. 2009;94(9):3215-3225.
Clinical Interventions in Aging

\section{Publish your work in this journal}

Clinical Interventions in Aging is an international, peer-reviewed journal focusing on evidence-based reports on the value or lack thereof of treatments intended to prevent or delay the onset of maladaptive correlates of aging in human beings. This journal is indexed on PubMed Central, MedLine,

\section{Dovepress}

CAS, Scopus and the Elsevier Bibliographic databases. The manuscript management system is completely online and includes a very quick and fair peer-review system, which is all easy to use. Visit http://www.dovepress. com/testimonials.php to read real quotes from published authors. 